\title{
The Civilised Self and the Barbaric Other: Imperial Delusions of Order and the Challenges of Human Security
}

Ikechi Mgbeoji

Osgoode Hall Law School of York University, imgbeoji@osgoode.yorku.ca

Source Publication:

Third World Quarterly. Volume 27, Number 5 (2006), p. 855-869.

Follow this and additional works at: https://digitalcommons.osgoode.yorku.ca/scholarly_works

Part of the Defense and Security Studies Commons, and the Military, War, and Peace Commons cc) (1) $(9)$

This work is licensed under a Creative Commons Attribution-Noncommercial-No Derivative Works 4.0 License.

\section{Recommended Citation}

Mgbeoji, Ikechi. "The Civilised Self and the Barbaric Other: Imperial Delusions of Order and the Challenges of Human Security." Third World Quarterly 27.5 (2006): 855-869.

This Article is brought to you for free and open access by the Faculty Scholarship at Osgoode Digital Commons. It has been accepted for inclusion in Articles \& Book Chapters by an authorized administrator of Osgoode Digital Commons. 


\section{The Civilised Self and the Barbaric Other: imperial delusions of order and the challenges of human security}

\section{IKECHI MGBEOJI}

ABSTRACT In the aftermath of the military conflicts of 1936-45, there seemed to be a global renunciation of war as an instrument of state policy. Shortly thereafter, however, decades of ideological attrition between the major powers and the inherent perversion of postcolonial states reduced the solemn declarations of 1945 to ineffectual rhetoric. Underpinning the decline and demise of a human-centred approach to global peace and security is the enduring notion of the civilised self and the barbaric other. The polarisation of humanity between camps of the savage and the civilised has continued to animate international policy making despite denials. This paper argues that a rejection of the polarities is imperative for the success of the emergent concept of human security.

In Collective Insecurity, ${ }^{1} \mathrm{I}$ examined the changing character of collective security in post-cold war Africa. I argued that both international institutions and the hypocrisy of powerful states have combined to encourage and abet the tyrannical capture of many African states and the reduction of several of them to pathetic sites for the egregious abuse of millions of people. Further, I posited that the reduction of several postcolonial states to 'geographies of injustice', ${ }^{2}$ especially in the cold war era, was a consequence of the prevailing militarised concept of security. In the past decade, however, a careful observer of contemporary world order would clearly see the re-emergence of a militarised concept of security.

Events in Afghanistan and Iraq evidence a return of a militarised concept of state security. A troubling aspect of this phenomenon is the revitalisation 
of the omperialistic notion of the barbaric other and the civilised self. By this logic the former is depicted as anarchic, primitive and in need of 'pacification' and civilisation. The process of pacification and civilisation often involves military attacks and vilification of those believed to be uncivilised. Embedded in this narrative is the belief that the 'savage' peoples of the global South, ${ }^{3}$ a diverse bloc of peoples, cultures and societies, are a menace and a threat to global peace.

From this prism complex and problematic issues such as international terrorism, ${ }^{4}$ Israeli -Palestinian conflict, 5 militant Islam, ${ }^{6}$ proliferation of weapons of mass destruction, ${ }^{7}$ epidemics and pandemics, ${ }^{8}$ and state failure are peculiarly construed as emanating from the 'anarchic', 'theocratic' and 'undeveloped' global South. In this binary conception of global security, the cause, location and site of resolving growing threats to global security are fixed in the global South. The metaphor of the global North as the overworked nanny, constantly at pains to supervise the 'development' of a delinquent, infantilised group of peoples, 9 is one that has for centuries underpinned so-called North -South relations. 10

Entwined in the praxis of this metaphor is the brutalisation of the 'savage' by the 'civilised'. The 'burden of taming the savages' entails a persistent pattern of brutality and imperialism. This process is historically evidenced in European colonialism and iterated in contemporary narratives of a 'violent Islamic world'. It is a process that has mutated over time while retaining its imperialistic essence. Inspired by certain ideological fundamentalisms and unyielding certitude, the cycle and pattern of a civilised self and a barbaric 
other is repeatedly re-enacted by colonialism, cultural imperialism, military depredations, and an unrelenting political and economic interference in the domestic affairs of the global South. ${ }^{11}$

In this paper I explore the metaphor of the civilised self and the savage other in the context of the emerging concept of human security. I interrogate the notion that the global South is the cause and origin of contemporary global insecurity. My thesis is that the North and South are mutually vulnerable, sharing a common destiny, which cannot be realised unless notions of a civilised self and a barbaric other are abandoned.

My analysis also questions the complicity and abetment of some scholars devoted to ideological certitudes of free market economies and Western-style democracy as a universal panacea for political and economic problems in the South. Of course, there are normative virtues in liberal philosophy which are indispensable for civilised existence. However, the history of the relations between the 'civilised self and the 'barbaric other' reveals a common and persistent pattern of domination of the 'barbaric' by the 'civilised', who nonetheless profess liberal ideals. The paradox, thus, is that the brutalisation of the 'savage' by the 'civilised' is a cause and effect of the civilising mission inherent in the certitudes, assumptions and dogmas of Western-style liberalism, persuaded by itself of the universality and superiority of its own habits, convictions and historical experiences.

My analysis is animated by theoretical approaches favoured by the Third World Approaches to International law (TWAIL). 12 Structurally and thematically this paper is divided into three parts. The first introduces the 
binary concept of civilisation, its influence on colonialism and state security. Colonialism and empire are explicated, not as epochs in human history but as radical and ongoing structural reconfigurations of the globe. The second part examines the limitations of the classical concept of state security and the emergence of the concept of human security. Part three scrutinizes the abuse and misuse of certain basic tenets of neoliberalism, such as democracy, human rights and free market systems, as apologia for the evisceration of human dignity in the global South. I argue that the perversion of neoliberal values of human dignity and freedom constitutes a threat to human security across the globe.

\section{The civilised self and the barbaric other}

Cultural chauvinism is nothing new and notions of the civilised self and the barbaric other are ancient. But the worrying aspect of this phenomenon is the brutalisation that the 'civilised' inflicts on the 'savage' in the name of enlightening and pacifying the latter. The savagery inherent in the civilisin5 mission stretches from the ridiculous Taliban obsession with lengthy beards 1 as a shibboleth of piety, to the genocide of the American natives by European imperialists. ${ }^{14}$

Indeed, a notion of the civilised self and the barbaric other underpins the infamous North -South divide. The global North, 15 often described as the 'developed', 'advanced' countries of the world, is often contrasted with the 'developing countries', or Third World' nations of the world. ${ }^{16}$ The totalising impact of a shared history of extreme European colonialism and depredation 
in the past half millennium is often used as a touchstone in banding together a huge array of complexities. ${ }^{17}$

Modern history is filled with various forms of colonialism and conquest inspired by cultural chauvinism and economic exploitation, but none has been as violent and enduring in its radical transformation of the globe as European colonialism 18 in the global South. Imperial Europe adopted a religious and geopolitical campaign that bifurcated the world into a civilised Europe and a savage 'other'. This oppositional logic was the anchor for the unprecedented dispossession and genocide of colonised peoples and territories. 19

To be regarded as 'civilized', the 'savage' is required to imbibe and reproduce Eurocentric norms, values and institutions. As Makau Wa Mutua notes, within this prevailing logic of colonialism, 'history is a linear, unidirectional progression with the "superior" and "scientific" Western civilisation leading and paving the way for others to follow'.$^{20}$ In its totalising mission colonialism rarely roused itself to acknowledge the multitude of differences among peoples and cultures of the global South. ${ }^{21}$

European colonialism 22 did not countenance or acknowledge the complexity and diversity of the Islamic worlds. ${ }^{23}$ Imperial Europe surveyed the complexity and diversity of Islamic peoples and summed them all into one: a barbarous, stagnant, heathen and vile brood. This process, the birth of Orientalism in $1095,{ }^{24}$ summoned Europe to the first crusade against the 'enemies of God'. As Richard Falk has presciently observed, in such dualist conception, Islam was portrayed by scholarly discourse as an 
unchanging essence that can only produce uniformly oppressive political arrangements. In contrast, the 'Western mind is uniquely positioned as rational and coherent'.25

Orientalism seems to endure forever. Current rhetoric on the so-called 'Islamic mind', or 'Arab mind',26 as captured in the works of people like Samuel Huntington, reflects an uncritical acceptance of a totalising narrative of the civilised self and the barbaric other. In the so-called 'clash of civilisations' the Islamic world was often depicted 'as a monolithic and unitary structure, opposed to all that was modern and irremediably autocratic in state/society relations'. In recent times this binary logic has inspired the narrative that current spasms of violence by some disaffected Islamic militants is the product of 'Islam's failed encounter with modernity'! Once the depiction of the 'savage other' as an unruly horde is completed, the 'civilised self justifies its brutalisation of the former as a heaven-ordained task of pacification and civilisation. ${ }^{27}$ This mission, often backed with tremendous violence, is uniquely construed as an unavoidable task of creating order from the chaotic environment of the savage. To achieve this objective, international law and institutions were often summoned to the service of power and empire. International law could not have served imperialism well if it did not share and reflect the ethos, philosophies, temperament and delusions of empire. ${ }^{28}$

Having dispossessed the natives of the so-called 'backward territories' 29 of their lands, resources and cultures, the colonial powers proceeded to carve up the colonised territories. The resulting colonial states were brutal in their 
exploitation of the colonised. To maintain 'order' in the colonies, the 'civilised self had to rely on a militaristic concept of state security. As long as there were no direct military conflicts between states, the misery of the colonised was never considered to be a matter of state security. Thus the history of state formation in the global South, especially in Africa and in the Middle East, ${ }^{30}$ holds the key to an understanding of the degraded nature of state security in those territories. ${ }^{31}$

Imperialism required the sustenance of non-democratic political entities in the colonised territories and the economic humiliation of the colonised. ${ }^{32} \mathrm{At}$ the dawn of political independence many newly decolonised states were deliberately looted and impoverished. In some cases monarchs were created overnight. As outposts of empire many colonial states $^{33}$ were mere conduit pipes for the transfer of resources to the imperial metropolis. Peace of the graveyard was mistaken for peace!

Why did such a denuded concept of humanity survive for so long? Three interrelated factors may be posited. First, colonial states were creatures of a world order fashioned on the Westphalian paradigm, with its rigid deference to the canons of non-intervention in the internal affairs of other states. Second, colonial states lacked local institutions for the humane and legitimate regulation of power. Third, the prevailing praxis of state security did not encompass 'the development of human dignity and basic rights'.

At the formal end of colonialism the first generation of rulers in many postcolonial states tended to perpetuate the militarised concept of state security to secure their tenuous hold on power. Effective control over the 
newly 'decolonised' territories became a licence to pillage the state and oppress the citizenry. In addition, cold war politics afforded ample shield from critical external gaze. The rule of 'big men' and thugs converted colonies into personal fiefdoms.

The brutalisation of the citizenry was often justified on the spurious and nebulous grounds of 'state security' and the alleged need to maintain 'peace and stability' in the state. The maxim salus populi suprema lex (the safety of the people is the supreme law) was widely invoked by dictators and tyrants to justify the enslavement of people. By an adroit mixture of coercion and corruption of the domestic order and deft manipulation of the international security paradigm, tyrants held sway in their respective domestic domains. The impoverishment of the concept of security through perverted methods could not have succeeded without the active connivance of powerful states and institutions.

Special attention must be paid to the self-serving and wicked foreign policies of imperial powers and the impact of such policies of global security. The defunct Soviet Union, for example, engaged in systematic brutality, widespread atrocities and the ruthless suppression of independent thought in Eastern Europe. Similarly, the USA engaged in what it characterised as 'low intensity conflict', a euphemism for the gradual, systematic and sustained destruction of regimes and peoples opposed to its policies across the world. In Nicaragua, for example, President Reagan once described the bandit Contras as 'the moral equivalent of our Founding Fathers'. ${ }^{34}$ 
In the name of spreading democracy and a free market economy the USA has supported and in many cases installed right-wing military dictatorships in the global South. French and Belgian troops were routinely dispatched to prop up tyrants in Africa. Millions of peoples in the global South have perished as a result of US-supported aggression, policies and terrorism in postcolonial territories.

The militarised concept of security is also evidenced by the arms race during the Cold War. With 702 military installations throughout the world in 132 countries, the USA possesses 8000 active and operational nuclear warheads (2000 of which are on hair trigger alert, ready to be launched with 15 minutes warning), thousands of chemical and biological warheads, thousands of military aircraft, and hundreds of battle-ready warships. With such a deadly arsenal, the question remains whether the world is necessarily a secure place.

\section{Collective security: the limits of armed force}

The concept of collective security is premised on the notion that 'peace is universal and indivisible'.35 In its classical formulation, collective security purports that an alliance of states with similar values and interests is a reliable bulwark against unilateral aggression. ${ }^{36}$ Collective insecurity operates on the idea that the presence of an overwhelming collective military force operating in a multilateral framework is a deterrent to errant unilateral aggression. 37 The Wilsonian ideal of a 'universal government of all states' never really saw the light of day. ${ }^{38}$ Nevertheless, 
the carnage ${ }^{39}$ in the so-called world wars $^{40}$ persuaded many states that global security was best secured through a multilateral regime. Inasmuch as the notion of peace was construed to be the absence of war, the UN Charter acknowledged the relationship between state security and human dignity. ${ }^{41}$ More importantly, the UN Charter underscored the limitations of a unilateral pursuit of security and in its stead sought to institutionalise a regime of collective security with some focus on the human aspects of security. ${ }^{42}$

Although collective security transcends global machineries for enforced compliance with international law, the imperatives of international justice, rule of law and opportunity to live a fulfilled life 43 were largely sacrificed at the altar of cold war politics. However, whether one subscribes to the views of the interdependence theorists 44 or to those of the neo-institutionalists, it was becoming increasingly clear, especially in the aftermath of the Cold War, that security could no longer be limited to preparation for war. ${ }^{45}$ Thus the end of the Cold War inspired a movement towards a rethinking of the militarised concept of security. 46

The intimations of a Grotian moment in the mid-1980s 47 questioned some of the fundamentalisms of the Cold War. Some global problems such as terrorism (international and state-sponsored), drug trafficking, organised crime, environmental degradation, and unfair trade practices and policies were increasingly recognised as threats to international peace and security. 48 The militaristic conception of security, particularly in an age when the most 
dangerous threats to security require holistic approaches, ${ }^{49}$ became ineffectual, if not anachronistic, 50 in the face of such global issues. If security had to be meaningful, 51 its definition and praxis had to appreciate the imRortance of the individual human, both as a subject and an object of security. ${ }^{2}$

The centring of the individual at the core of security is captured under the emerging concept of human security, 53 a term most often associated with the 1994 Human Development Report on Human Security 54 by Mahbub ul Haq. Although the 1994 report has been credited with giving prominence to the concept of human security, a human-centred conct of security is immanent in the various international instruments preceding formation of the United Nations. Instruments such as the UN Charter, the Universal Declaration of Human Rights, the Genocide Convention and the 1949 Geneva Conventions and their Additional Protocols make allusions to human security. 56 The 1994 report identifies four essential characteristics of human security, namely, universality, interdependence, prevention and anthropocentricity of security.57 The sovereignty of the human being is inescapable. A caution must be added here. Bodily soverenty cannot always be equated with human security. 58 Human security 5 describes some balance between the need for safety and the necessity of freedom. Absolutism in respect of either safety or freedom would be naive and useless.

Threats to human security may be direct or indirect in their origins. Efforts geared towards a systemic approach to organising these conceptualisations into a coherent structure of international security underscore the theoretical 
complexity of the concept of human security. ${ }^{60}$ Although human security is a noble idea, 61 the question remains whether the concept has any constructive impact on the behaviour or policies of states. Secondly, how is human security to be realised in an era when governments use fear of terrorism as a policy of choice? 62

\section{The constructivist impact of human security}

The international order on peace and security is not short of grand and noble ideas that died on the vine. There are several noble concepts that states ostensibly celebrate but which are rarely applied or adopted in their policies. Human security is a concept that most states would give rhetorical approval to but of whose meaning few have a clear idea, let alone knowing how it would be implemented. A potential drawback in the unwieldiness of the concept of human security is the arbitrariness of choice that its vagueness offers potential admirers. With the notable exceptions of Canada and Japan, no state has articulated its foreign policy in the light of this theoretical paradigm shift.

Human security is part of the more general project of global governance, with all the attendant contradictions, challenges and trepidations. Is human security constructive and how best could it be operationalised? In teasing out the answers to this question, four main aspects of the concept of human security must be considered: state violence, environmental degradation, population displacement and globalisation. Bearing these four factors in mind, there are three main approaches to the constructivism and 
implementation of human security. Each approach reflects a dimension of human security. These dimensions are freedom from fear or rather, the safety of the individual; guarantee of human rights and rule of law; freedom from poverty; and the institutionalisation of social justice. ${ }^{63}$

The first dimension, indeed a school of thought on human security, conceives of human security broadly enough to encompass the rule of law and international treaties, and multilateralism as vectors for restoring human security. Needless to say, this approach is neoliberal and may be construed as an extension of Kantian democratic peace. ${ }^{64}$ On a slight different level the construction of human security from the building blocks 5 of human rights is premised on three related mechanisms, namely, sanctioning, shaming, and co-optation of deviant states into the family of nations. 66 Both approaches are constructive. They both rely on group sanctions to correct and restrain deviant states. Sanctions and similar group rebukes confine or limit the ability of the deviant to access goods, services and capital markets until such a time when the deviant behaviour has been sufficiently modified.

This method of implementing human security is effective only if the elites in the offending state are vulnerable enough to international services, goods and capital markets to impel them to adopt prescribed normative changes. It is ineffective when the errant state is a powerful entity driven by its own permutations of good and evil and impervious to group rebuke. Effective shaming or rebuke relies on a group's shared sense of outrage and values. The assumption here is that there is a body of acceptable modes of behaviour 
to which all states, regardless of their historical and contemporary experiences have subscribed. What happens when the errant state is unabashedly proud of its deviant status? Or when the group is polarised on North -South lines?

Again, there is an assumption that all states have an equal sense of shame. Where such assumption is untenable, misplaced or exaggerated, deviations from acceptable norms induce little or no shame to the offending states. Indeed, as in the case of the US invasion of Iraq, such errant behaviour could metamorphose into patriotic fervour! Similarly, co-optation relies on a complex system of 'verification' whereby the behaviour of offending states on human rights is routinely checked and evaluated. 67 The problem with this approach is that in most cases the 'civilised self performs the task of evaluating the behaviour of the 'barbaric other'. Biases and inconsistencies in the evaluations are bound to occur. For example, while North Korea and Iran have been condemned for their nuclear ambitions, Pakistan and Israel, two notorious nuclear powers, have escaped rebuke. Such inconsistency undermines human security.

The second dimension to human security is the humanitarian aspect, with a focus on the safety of the individual, especially in the event of war. This approach is institutionalised by the establishment of the International Committee of the Red Cross, and humanitarian treaties such as the Hague Conventions regarding the laws of war. By creating a normative regime for the conduct of war, the humanitarian approach underscores the safety of the individual as a tenet of civilisation. The profound impact of this approach is 
the outlawry of war itself as an instrument of national policy. Two additional concepts, namely, peace maintenance and conflict prevention, have been perceived as instruments of human security. Peacekeeping, peace building and humanitarian assistance are logical extensions of this dimension of human security.

The third and perhaps most problematic aspect of human security is individual sustainable development. This approach focuses on non-military factors that threaten human security and survival. This aspect of human security is heterogeneous, taking into account population explosion, environmental degradation, fair trade and chronic poverty. This dimension of human security probably derives from international agreements on economic, social and cultural rights. Without question this is the most contentious and elusive dimension of human security.

\section{The persistence of falsehood and imperial delusions of order}

Human security requires institutionalised responses to factors that diminish human worth. The paradox here is that the state, supposedly a guarantor of human dignity, has been the most prolific destroyer of humanity. ${ }^{68}$ Governments of all ideological persuasions have been much more fatal to humanity than all natural tragedies combined. It has been estimated that over 169 million people have been killed since the start of the 20th centur4 by both totalitarian and liberal-democratic governments across the world. ${ }^{6}$

It is therefore not surprising that the human rights regime is preoccupied with taming and reining in the feral proclivities of the state. As Makau wa 
Mutua observed in his seminal critique of the conception of the state as a predator:

The human rights story presents the state as the classic savage, an ogre forever bent on the consumption of humans. The human rights corpus is ostensibly meant to contain the state, for the state is apparently the raison d'etre for the corpus. Although savagery in human rights discourse connotes much more than the state, the state is depicted as the operational instrument of savagery. States become savage when they choke off and oust civil society. The 'good' state controls its demonic proclivities by cleansing itself with, and internalizing, human rights. The 'evil' state, on the other hand, expresses itself through an illiberal, anti-democratic, or other authoritarian culture. The redemption or salvation of the state is solely dependent on its submission to human rights norms. The state is the guarantor of human rights; it is also the target and raison d'etre of human rights law. ${ }^{70}$

The notion of the state as a feral predator finds loud and iterative voices in scholarly cogitations and institutional measures. ${ }^{71}$ The statistics on state predation on humanity are monumental. ${ }^{72}$ Given that the global South is often portrayed as the global epicentre for state brutality, 73 it follows that virtually all human rights organisations are focused on identifying and shaming the 'savages' of the global South. Notwithstanding egregious human rights abuses in all parts of the world, the global South is synonymous with human rights abuses.

However, the narrative of the global South as a feral predator often overlooks the cultural foundations of modern postcolonial states. Again, as 
Makau wa Mutua presciently observes:

While the metaphor (of the state as a predator) may suggest otherwise, it is not the state per se that is barbaric but the cultural foundation of the state. The state only becomes a vampire when 'bad' culture overcomes or disallows the development of 'good' culture. The real savage, though, is not the state but a cultural deviation from human rights. That savagery inheres in the theory and practice of the one-party state, military junta, controlled or closed state, theocracy ... not in the state per se. The state itself is a neutral, passive instrumentality-a receptacle or an empty vessel-that conveys savagery by implementing the project of the savage culture...The human rights corpus, though well meaning, is fundamentally Eurocentric, and suffers from several basic and interdependent flaws captured in the Savage -Victim -Saviour metaphor. First, the corpus falls within the historical continuum of the Eurocentric colonial project, in which actors are cast into superior and subordinate positions. Precisely because of this cultural and historical context, the human rights movement's basic claim of universality is undermined. Instead, a historical understanding of the struggle for human dignity should locate the impetus of a universal conception of human rights in those societies subjected to European tyranny and imr,erialism. Unfortunately, this is not part of the official human rights narrative. ${ }^{4}$

The moral is that, if human security is to be realised, the instinctive demonisation of the global South must be replaced by a rational, transparent and effective assessment of the perverse foundations and contemporary decay 
of the postcolonial state itself. In particular, there must be a critical inquiry into the role of the 'civilised self in the processes that led to the present situation. This is a task that requires sensitivity to history, courageous confrontation with ugly facts, and the political will to make necessary amends. It is a task that must appreciate the inherent rights of peoples to organise themselves in accord with their resources, socioeconomic demands and spiritual world-view. A linear conception of history, with the global North as the touchstone of 'civilisation' and the rest of the world playing 'catch-up' is inconsistent with the concept of human security. Freedom is at the core of human security. As Makau wa Mutua has eloquently argued:

The zeal to see all humanity as related and the impulse to help those defined as in need is noble... a certain degree of human universality is inevitable and desirable. But what that universality is, what historical and cultural stew it is made of, and how it is accomplished make all the difference ...the [imperial] zeal to save others--even from themselves-is steeped in western and European history. If one culture is allowed the prerogative of imperialism, the right to define and impose on others what it deems food for humanity, the very meaning of freedom will have been abrogated. ${ }^{7}$

Condescending claims, especially on the alleged inability of Africans, Arabs, Muslims, etc to 'rise above the centrifugal pull of tribalism' 76 must yield to a better understanding of the historical roots of human insecurity. ${ }^{77}$ The totalising imagery of 'ethnic groups', 'tribes' and 'pre-modern' peoples blinded 
by the lights of European modernisation, and hence unable to grope their way out of anarchic and failing states, ${ }^{78}$ is a rhetoric that obscures the structural pathologies of the postcolonial state. Retailers of this sanitised version of history ignore the 'ethnic' foundations of European states.

The restructuring of the state may require redrawing the current boundary lines of some states in Africa ${ }^{79}$ and in Arabia, and the promotion of a regime of self-determination of peoples. Arguments for the perpetuation of the status quo, especially in egregious cases such as the Kurdish question, are irresponsible and mischievous. ${ }^{80} \mathrm{~A}$ redrawing of boundaries is not always a terrible thing. ${ }^{81}$ The focus should be on how to peacefully reorganise the patchwork of colonially balkanised peoples to become 'geographic spaces of peace and prosperity'.

Beyond restructuring flawed states of the global South, the foreign policies of states of the global North must be critically evaluated. In this regard both neoliberal fundamentalisms such as 'free markets' and riht-wing imperial delusions of the 'clash of civilizations' must be restrained. ${ }^{8}$ For far too long millions of people in the global South have been massacred by proxies of the global North in the name of imposing democracy and a free market. ${ }^{83}$ While neoliberal ideologues may extol the wonders of Kantian democratic peace, the fact of the matter is that many so-called democracies are implicated in the under-reported but lethal conflicts in the global South. ${ }^{84}$ From Vietnam to Nicaragua, and from Afghanistan to Iraq, various atrocities have been committed in the name of freedom and free markets. ${ }^{85}$ The fundamentalism of Bin Laden may not be much different in thought patterns, prescriptions, 
moral certitude and totalising imagery as that of those who slaughter the innocents in the name of freedom. ${ }^{8} 6$

Military victories by imperial powers in states of the global South ${ }^{87}$ sow the seeds of future tragedy. It was the Gulf war and the establishment of US military bases in Arabia that partly motivated and inspired Osama bin Laden to create the al-Qaeda network. In addition to the slaughter of innocents and the vicious cycles of violence created by imperial delusions of order, the environmental costs of imperial conquests are enormous. For example, in Afghanistan ${ }^{88}$ the USA used between 500 and 1000 metric tons of depleted uranium in munitions to attack bunkers, caves and other hardened targets. ${ }^{89}$ Perhaps the most virulent manifestation of the gladiatorial approach to security is the Bush Doctrine of 1 June 2002.90 The National Security Strategy (NSS) paper issued by the White House ${ }^{91}$ on 17 September 2002 iterated the Bush Doctrine. The NSS asserts a US right to undertake preemptive attacks against potential aggressors, cutting off planned, perceived or future attacks before they can occur. The NSS contains no clear definition of what constitutes 'sufficient threat to [US] national security'. Thus, there is ample room for arbitrary implementation. As Henry Kissinger, a man not known for his deference to international law warned, 'it cannot be in either the American national interest or the world's interest to develop principles that grant every nation an unfettered right of pre-emption against its own definition of threats to its security' .92 The Bush Doctrine repudiates multilateral approaches to both collective and human security and confirms the theory that the USA, and indeed other imperial Rowers, 
only pursues multilateralism and diplomacy when it is convenient for it. ${ }^{93}$ Interestingly, but not surprisingly, the Bush doctrine is imbued with neoliberal rhetoric on the rule of law, respect for private property, democracy, free markets, and so on. ${ }^{94}$

Beyond such neoliberal pretensions the hypocrisy of imperial powers in matters of collective and human security, in and of itself, undermines human security. ${ }^{95}$ For example, the USA continues to support the decadent regime in Saudi Arabia and sustains many tyrants. The USA and other imperial states have been instrumental in spreading weapons of mass destruction. ${ }^{96}$ The foreign policies of several powerful states of the global North are often indistinguishable from those of notorious rogue states. ${ }^{97}$ The USA ${ }^{98}$ is as guilty of international state terrorism (bombing of Sudan) and statesponsored terrorism (Contras in Nicaragua) as some of the notorious members of the so-called 'axis of evil'.

Often imperial delusions of order are justified on the basis that the UN has become sclerotic. ${ }^{99}$ While it is generally accepted that the UN has failed or under-performed in several respects, neither the Bush Doctrine nor imperial delusions of order are acceptable. 100 The world would be in worse shape if the UN did not exist. Recent statistics unveiled by Human Security Centre in 2005 show that, since 1992, the number of armed conflicts has dropped by $40 \%$. This unheralded decline is linked to a dramatic increase in UN conflict prevention and peace building efforts. 101

Confounding conventional wisdom, the report reveals that all forms of political violence, except international terrorism, have declined world-wide 
since the early 1990s. The reduction in the number of conflicts is attributable to the critical role played by the UN in spearheading a huge upsurge of international conflict prevention, peacekeeping and peace-building activities. There is still much work to be done, however. Crises cannot be the main criteria for evaluating the adequacy or lack thereof of institutions designed for the maximisation of human dignity. ${ }^{102}$ 


\section{Notes}

I Ikechi Mgbeoji, Collective Insecurity: The Liberian Crisis, Unilateralism \& Global Order, Vancouver: University of British Columbia Press, 2003.

2 Upendra Baxi, 'Geographies of injustice: human rights at the altar of convenience', in C Scott (ed), Torture as Tort: Comparative Perspectives on the Development of Transnational Human Rights Litigation, Oxford: Hart Publishing, 2001.

3 B Rajagopal, 'Locating the Third World in cultural geography', Third World Legal Studies, 1, 198889, pp 1 -12; K Mickelson, 'Rhetoric and rage: Third World voices in international legal discourse', Wisconsin International Law Journal, 16, 1994, pp 353-360.

4 Ikechi Mgbeoji, 'The bearded bandit, the outlaw cop, and the naked emperor: towards a NorthSouth deconstruction of the text and contexts of international law's disengagement with terrorism', Osgoode Hall Law Journal, 43(2), 2005, pp 105-135.

5 Tony Judt, 'Israel: the alternative', New York Review of Books, 50 (16), 2003, pp I -7.

6 A Rashid, Taliban: Militant Islam, Oil and Fundamentalism in Central Asia, New Haven, CT: Yale University Press, 2000; Rashid, Jihad: The Rise of Militant Islam in Central Asia, New York: Penguin Books, 2003; and RB Wright, Sacred Rage: The Wrath of Militant Islam, New York: Simon \& Schuster, 2001.

7 James Kraska, 'Averting nuclear terrorism: building a global regime of cooperative threat reduction', American University International Law Review, 20, 2005, pp 703712; and Miriam Sapiro, 'Iraq: the shifting sands of preemptive self-defense', American Journal of International Law, 97, 2003, pp 599615 .

8 Obi Aginam, 'Global village, divided world: South North gap and global health challenge at century's dawn', Indiana Journal of Global Legal Studies, 7, 2000, pp 603-620; and Lauren Asher, 'Confronting disease in a global arena', Cardozo Journal of International and Comparative Law, 9, 2001, p 35.

9 See Mohamed Bedjaoui, 'Poverty of the international order', in R Falk, F Kratochwil \& S Mendlovitz (eds), International Law: A Contemporary Perspective, Boulder, CO: Westview, 1985, p 153; David Slater, 'Contesting occidental visions of the global: the geopolitics of theory and North-South relations', Beyond Law, December 1994, pp 97 I 06; and Convention Concerning the Protection and Integration of Indigenous and other Tribal and Semi-Tribal Populations in Independent Countries, 26 June 1957, reprinted in 328 United Nations Treaty Series (UNTS), 328, p 247.

10 David L Peterson, 'Debunking ten myths about democracy in Africa', Washington Quarterly, 17, 1994, pp 129-140.

11 Nancy Chang, Silencing Political Dissent-How Post-September 11 Anti-Terrorism Measures threaten our Civil Liberties, New York: Seven Stories Press, 2002.

12 M Mutua, 'What is TWAIL?', American Society of international Law (ASIL) Proceedings, 94, 2000, pp 31 -35; A Anghie, et al (eds), The Third World and International Order: Law, Politics, and Globalization, Leiden: Martinus Nijhoff, 2003; J Gathii, 'International Jaw and Eurocentricity', European Journal of International Law, 9, 1998, p 184; and OC Okafor, 'Newness, imperialism, and international legal reform in our time: a TWAIL perspective', Osgoode Hall Law Journal, 171 (43), 2001, pp 174-180.

13 Zia Sarhadi, 'Taliban's "Islamic Emirate": what will they think of next?', available online at http:// www.muslimedia.com/archives/world98, accessed 20 October 2005. See also 'Taliban measure beards with lantern glass', NNI, 3 December 1998, at www.rawa.org/beard.html, accessed 20 October 2005.

$14 \mathrm{C}$ Chandrasekha, 'Flying while brown: federal civil rights remedies to post-9/11 airline racial profiling of South Asians', Asian Law Journal, 10, 2003, pp 215-230; and M Ahmad, 'A rage shared by law: post-September 11 racial violence as crimes of passion', California Law Review, 92, 2004, p 1259.

15 See OECD in Figures: Statistics on the Member Countries, Supplement to the OECD Observer, 152, 1988 , pp 4-5; and A Sawyer, 'Marginalization of Africa and human development', African Journal of International and Comparative Law (AJICL), 5, 1993, p 176.

16 N Adams, Worlds Apart: The North-South Divide and the International System, London: Zed Books, 1993.

17 I Seidl-Hohenveldern, International Economic Law, Dordrecht: Martinus Nijhoff, 1989, p 4; and W Langley, 'The Third World: towards a definition', Boston College Third World Law Journal, 2 (1), 1981, pp 1-12.

18 Cerebrating on Columbus and his legacy-protest obscures the large point: repeating pattern of European conquest', Editors Report, 17 October 2005, at http://www.msnbc.msn.com/id/9664359/, accessed 8 November 2005.

19 Ikechi Mgbeoji, Global Biopiracy: Patents, Plants, and Indigenous Peoples, Vancouver: University of British Columbia Press, 2005, pp 85-87.

20 Makau Wa Mutua, 'Savages, victims and saviours: the metaphor of human rights', Harvard International Law Journal, 42 (1), 2001, pp 201-245.

21 Guillermo Floris Margadant, 'Official Mexican attitudes towards the Indians: an historical essay', Tulane Law Review, 54 (2), 1980, pp 967-995.

22 Makua wa Mutua, 'What is TWAIL?'.

23 Zachary Lockman, Contending Visions of the Middle East: The History and Politics of Orienta/ism, Cambridge: Cambridge University Press, 2004, pp 27-30. The term 'Middle East' is equally Eurocentric.

24 Falk, 'Imperial vibrations, 9/11, and the ordeal of the Middle East', Paper 23, Global and 
International Studies Program, University of California at Los Angeles, 2005, p 8.

25 Lockman, Contending Visions of the Middle East, p 176.

26 Ibid, p 175.

27 Douglas Sanders, 'The re-emergence of indigenous questions in international law', Canadian Human Rights Yearbook, Vancouver: UBC Press, 1983, pp 1-15.

28 Mark Javis (ed), The Influence of Religion on the Development of International Law, Dordrecht: Martinus Nijhoff, 1991.

29 Mark Lindley, The Acquisition and Government of Back ward Territory in International Law: Being a Treatise on the Law and Practice relating to Colonial Expansion, New York: Longman, 1969.

30 Tony Judt, 'Israel: the alternative'.

31 James Crawford, The Creation of States in International Law, Oxford: Oxford University Press, 1979.

32 EK Quashigah, 'Protection of human rights in the changing international scene: prospects in subSaharan Africa', AJICL, 6 (1), 1994, pp 93-95.

33 General Act of the Conference of Berlin, reprinted in RJ Garvin \& JA Betley (eds), The Scramble for Africa: Documents on the Berlin West African Conference and Related Subjects 1884-1885, London: Longman, 1973.

34 See Harold Pinter, Nobel Prize Speech, available online at http://nobelprize.org/literature/laureates/ 2005/pinter-lecture-e.html.

35 RA Akindele, The Organization and Promotion of World Peace-A Study of UniversalRegional Relationships, Toronto: University of Toronto Press, 1976, pp 3-6.

36 Hans Kelsen, Collective Security at International Law, Washington, DC: US Government Printing Office, 1957, p 3.

37 Henry Kissinger, A World Restored, New York: Grosset \& Dunlap, 1964, pp 11-12.

38 MV Naidu, Collective Security and the United Nations-A Definition of the UN Security System, New York: St Martins Press, 1974, pp 4-5.

39 Grant Dexter, Canada and the Building of Peace, Toronto: Canadian Institute of International Affairs, 1944, p 141.

40 The events usually described as 'world wars' are better understood as intra-regional struggles for the control of Europe. Richard Falk, 'Imperial vibrations'.

41 Obiora Okafor, 'Is there a legitimacy deficit in international legal scholarship and practice?', International Insights, 17 (1), 1997, pp 91-120.

42 International Covenant on Civil and Political Rights, 999 UNTS, 1996, p 171.

43 lnis Claude, Swords into Ploughshares, New York: Random House, 1964, pp 32-38.

44 Robert Keohane \& Joseph Nye, Power and Interdependence: World Politics in Transition, Boston, MA: Little, Brown, 1977; and Robert Keohane, After Hegemony, Princeton, NJ: Princeton University Press, 1984.

45 Stephen Walt, 'The renaissance of security studies', International Studies Quarterly, 35 (!), 1991, pp 35-40.

46 Richard Falk, 'A new paradigm for international legal studies: prospects and proposals', in Falk et al, International Law, pp 651702.

47 Frederick Kratochwil, 'Sovereignty as dominium', in Gene Lyons \& Michael Mastanduno (eds), Beyond Westphalia? State Sovereignty and International Intervention, Baltimore, MD: Johns Hopkins University Press, 1995, pp 23-30.

48 Khatchik Derghoukassian, Human Secrity: A Brief Report on the State of the Art, Dante B Fascell North-South Center Working Paper No 3, November 2001, p I.

49 Janne Nolan (ed), Global Engagement: Cooperation and Security in the 21st Century, Washington, DC: Brookings Institution, 1994.

50 Karsten Nowrot \& Emily Schabada, 'The use of force to restore democracy: international implications of the ECOWAS intervention in Sierra Leone', American Journal of International Law, 92 (!), 1998, pp 1-55.

51 Jost Dulbreck, 'Globalization of law, politics, and markets: implication for local law-a European perspective', Indiana Journal of Global Legal Studies, 1 (!), 1993, pp 9-36.

52 Rob Macrae \& Don Hubert, Human Security and the New Diplomacy: Protecting People, Promoting Peace, Montreal: McGill-Queen's University Press, 2001.

53 Sabina Alkire, 'A conceptual framework for human security', CRISE Working Paper 2, on file with the author.

54 See http://www.undp.org/hdro/e94over.htm.

55 E Rothschild, 'What is security?', Daedalus, 124, 1994, pp 53-98.

$56 \mathrm{H}$ Hafterdorn, 'The security puzzle: theory building and discipline building in international security', International Security Quarterly, 31, 1991, pp 3-17.

57 Freedom from Fear, Department of Foreign Affairs and International Trade, Canada, 2004.

58 Kanti Bajpai, Human Security: Concept and Measurement, Kroc Institute Occasional Paper 19, August 2000.

59 Edward Newman, 'Human security and constructivism', International Studies Perspectives, 2001, 2 (3).

60 Roland Paris, 'Human security: paradigm shift or hot air?', International Security, 26 (2), 2001, pp 87-102.

61 Lloyd Axworthy, 'Canada and human security: the need for leadership', International Journal, Spring 1997, pp 183-196. 
62 Freedom from Fear.

63 Peter Stoet, Human and Global Security: An Exploration of Terms, Toronto: University of Toronto Press, 1999.

64 Fen Hampson, Jean Daudelin et al, Madness in the Multitude: Human Security and World Disorder, Oxford: Oxford University Press, 2001.

65 Jack Donnely, 'Human dignity, human rights and political regime', American Political Science Review, 80 (4), 1986, pp 801-820.

66 Margaret Doxey, United Nations Sanctions: Current Policy Issues, Halifax: Centre for Foreign Policy Studies, Dalhousie University, 1999.

67 Obiora Chinedu Okafor, 'The African system of human and people's rights, quasi-constructivism, and the possibility of peacebuilding within African states', International Journal of Human Rights, 8 (4), 2004, pp 413-450.

68 John Norton Moore, 'Beyond the democratic peace: solving the war puzzle', Virginia Journal of International Law, 44, 2004, p 341.

69 Rudolph J Rummel, Death by Government, New Brunswick, NJ: Transaction Press, 1994.

70 Makau wa Mutua, 'Savages, victims, and saviors: the metaphor of human rights', Harvard International Law Journal, 42 (!), 2001, pp 201-250.

71 Nsongurua J Udombana, 'Can a leopard change its spots? The African Union Treaty and human rights', American University International Law Review, 17 (3), 2002, pp 1177-1200.

72 New Partnership for Africa's Development (NEPAD), 2001, para 4, at http://www.uneca.org/nepad/ nepad.pdf.

73 See Decision on Refugees, para 1, Organisation of African Unity (OAU) Council of Ministers, OAU Doc CM/Dec 574 (LXXIII), 2000.

74 Mutua, 'Savages, victims, and saviors', p 204.

75 Ibid.

76 William Pfaff, 'A new colonialism? Europe must go back to Africa', Foreign Affairs, 74, 1995, p I; and Ali Mazrui, 'The message of Rwanda: recolonize Africa?', New Perspective Quarterly, 2 (4), 1994,p 18.

77 A Selassie, 'Ethnic identity and constitutional design for Africa', Stanford Journal of International Law, 29, 1992, pp 12-25.

78 Okechukwu Oko, 'Partition or perish: restoring social equilibrium in Nigeria through reconfiguration', Indiana International \& Comparative Law Review, 8 (2), 1998, pp 317-330.

79 Richard Mukisa, 'Toward a peaceful resolution of Africa's colonial boundaries', Africa Today, 44 (!), 1997, p 7.

80 Hemy Richardson, 'Failed states, self determination, and preventive diplomacy: colonialist nostalgia and democratic expectations', Temple International \& Comparative Law Journal, 10 (1), 1996, pp 45-60.

81 Makau wa Mutua, 'Putting Humpty Dumpty back together again: the dilemma of a post-colonial African state', Brookings Journal of International Law, 21 (2), 1995, pp 5-15.

82 Mukisa, 'Toward a peaceful resolution of Africa's colonial boundaries', p 21.

83 Ali Mazrui, 'The African as a political refugee: institutional collapse and human displacement', International Journal of Refugee Studies, July 1995, pp 22-30.

84 Rashidi Khalidi, Resurrecting Empire: Western Footprints and America's Path in the Middle East, Boston, MA: Beacon Press, 2004, p 175.

85 Upendra Baxi, 'Market fundamentalisms: business ethics at the altar of human rights', Human Rights Law Review, 5 (1), 2005, pp 1-26.

86 Joanne Gowa, Ballots and Bullets: The Elusive Democratic Peace, Princeton, NJ: Princeton University Press, 1999.

87 Stuart Bremer, 'Dangerous dyads: conditions affecting the likelihood of interstate war, 1816-1965', Journal of Conflict Resolution, 36 (2), pp 309-341; and Paul Diehl \& Gary Goertz, War and Peace in International Rivalry, Ann Arbour, MI: University of Michigan Press, 2000.

88 Paul Barker, 'Queries from Afghanistan', Friends Journal, September 2003, pp 1-10.

89 Ibid.

90 George W Bush, 'Commencement Address at the United States Military Academy in West Point, June 1, 2002', 38 Weekly Comp Pres Doc 944, 946, 10 June 2002.

91 The National Security Strategy of the United States of America', 15 September 2002, available at http://www.whitehouse.gov.nsc/nss.pdf.

92 Henry Kissinger, 'Consult and control: bywords for battling the new enemy', Washington Post, 16 September 2002, p A19. See also Justice Robert Jackson in Koretmasu v United States, 323 US 214 AT 246 (1944).

93 Joan Hoff, 'The American Century: from Sarajevo to Sarajevo', Diplomatic History, 23 (2), 1999, p 285.

94 James Rubin, 'Stumbling into war', Foreign Affairs, 82 (4), 2003, p 46.

95 Madeline Albright, 'Bridges, bombs, or bluster?', Foreign Affairs, 82 (5), 2003, pp 1-2.

96 Ikechi Mgbeoji, 'Prophylactic use of force in international law: the illegitimacy of Canada's participation in "coalitions of the willing" without United Nations authorization and parliamentary sanction', Review of Constitutional Studies, 8 (2), 2003, pp 169-202.

97 Marjorie Cohn, 'Understanding, responding to, and preventing terrorism', Arab Studies Quarterly, 24 (2), 2002, p 25.

98 D Kreiger \& D Chafee, 'Facing the failures of the Nuclear Non-Proliferation Treaty regime', 
Humanist, 63 (5), 2003, p 7.

99 AL Goodhart, 'Some legal aspects of the Suez situation', in Philip Thayer (ed), Tensions in the Middle East, Baltimore, MD: Johns Hopkins University Press, 1958, pp 259-260.

100 Richard Gardner, 'Future implications of the Iraq conflict: neither Bush nor the "jurisprudes"', American Journal of International Law, 585, 97 (1), 2003, pp 2-10.

101 Human Security Report 2005, available online at www.humansecurityreport.info/index.

102 Hilary Charlesworth, 'International law: a discipline of crisis', Modern Law Review, 65 (1), 2002, pp 377-390. 